\title{
Retraction Note to: Utilizing ANFIS for prediction water absorption of lightweight geopolymers produced from waste materials
}

Ali Nazari ${ }^{1}$

Published online: 15 June 2020

(c) Springer-Verlag London Ltd., part of Springer Nature 2020

Retraction Note to: Neural Comput \& Applic (2013) 23:417-427 https://doi.org/10.1007/s00521-012-0934-1

The Editor-in-Chief has retracted this article [1] because it significantly overlaps with a number of articles including those that were consideration at the same time [2] and previously published articles [3-6]. Additionally, the article shows evidence of peer review manipulation. The authors have not responded to any correspondence regarding this retraction.

\section{References}

1. Nazari A (2013) Utilizing ANFIS for prediction water absorption of lightweight geopolymers produced from waste materials. Neural Comput Appl 23:417-427. https://doi.org/10.1007/s00521-0120934-1
2. Nazari A (2013) Artificial neural networks application to predict the compressive damage of lightweight geopolymer. Neural Comput Appl 23:507-518. https://doi.org/10.1007/s00521-0120945-y

3. Nazari A (2012) Fuzzy logic for prediction water absorption of lightweight geopolymers produced from waste materials. Ceram Int 38(6):4729-4736. https://doi.org/10.1016/j.ceramint.2012.02. 058

4. Nazari A, Riahi S, Bagheri A (2012) Designing water resistant lightweight geopolymers produced from waste materials. Mater Des 35:296-302. https://doi.org/10.1016/j.matdes.2011.09.016

5. Nazari A, Riahi S (2012) RETRACTED: Experimental investigations and ANFIS prediction of water absorption of geopolymers produced by waste ashes. J Non-Cryst Solids 358(1):40-46. https:// doi.org/10.1016/j.jnoncrysol.2011.08.022

6. Nazari A, Khalaj G (2012) Prediction compressive strength of lightweight geopolymers by ANFIS. Ceram Int 38(6):4501-4510. https://doi.org/10.1016/j.ceramint.2012.02.026

Publisher's Note Springer Nature remains neutral with regard to jurisdictional claims in published maps and institutional affiliations.
The original article can be found online at https:// doi.org/10.1007/s00521-012-0934-1.

Ali Nazari

alinazari84@aut.ac.ir

1 Department of Materials Science and Engineering, Saveh Branch, Islamic Azad University, Saveh, Iran 